\title{
Molecular studies on the epidemiology and pathogenicity of Clostridium difficile
}

\author{
SOAD TABAQCHALI
}

I first heard of Chris Booth long before I met him. Having qualified from St Andrew's University, Scotland, I went to work as a research fellow with Dr A M Dawson in Professor Sheila Sherlock's Medical Unit which was then housed in a hut perched on the rooftop of the Royal Free Hospital. Every Friday afternoon, international research workers in the unit used to disappear to attend a ward round conducted by Chris Booth at the Hammersmith Hospital. My colleagues assured me that these rounds were not to be missed and advised me to join them, adding the fact that when young ladies were present, Chris Booth performed even better. Alas, during the two years that I was at the Royal Free, I was unable to attend, but I can well believe them.

It was in 1964, after I had finished the general medical course at the Postgraduate Medical School, that I joined the Gastroenterology Unit as an unpaid clinical assistant for six months in order to prepare for the MRCP examination. During these months, and while Chris was away in Africa, I became involved in intubating patients with malabsorption caused by gastrectomy or by jejunal diverticulosis. It was Gilbert Thompson who asked whether I would be interested in investigating these patients. By the end of the six months, we had studied several patients and correlated their intestinal bacteriology with their $\mathrm{B}_{12}$ absorption and their faecal fat excretion and later related it to bile salt deconjugation. It was the beginning of a very stimulating and productive period which lasted until the end of 1970 . I subsequently obtained a grant from the Peel Foundation and later became a member of the MRC Intestinal Malabsorption Research Group and Assistant Lecturer in the Department of Medicine, which was now headed by Chris who had succeeded Sir John McMichael in 1966.

The gastoenterology unit was initially housed in a small laboratory in the old Lower Medical Corridor at Hammersmith Hospital and my colleagues at the time were Drs Michael Brain, Jimmy Stewart, Gilbert Thompson, Graham Neale, and Hermon Dowling. Later we were to be joined by Tim Peters and a young Australian, Bill Doe. The atmosphere was stimulating, sometimes electrifying. Each one of us worked on some aspect of absorption or mal- absorption and we were able to achieve high standards and compete at an international level.

My own studies took a leap forward when $\mathrm{Dr}$ Sherry Gorbach came from Boston to join us for one year. It was he who established at Hammersmith the methods for anaerobic bacteriology which he and his colleagues in Boston had already used in the investigation of normal subjects. ${ }^{.}$We developed a very warm relationship which continues to this day. Other colleagues joined us from overseas, in particular Henning Schjonsby from Bergen (now in Oslo) who did excellent work on the way in which bacteria interfere with $\mathrm{B}_{12}$ absorption.

Those years were extremely productive, culminating in my being asked to give the Quadriennial Review on 'Pathophysiological role of small intestinal bacterial flora' at the World Congress of Gastroenterology in Copenhagen in 1970.' These achievements were made possible by the support and encouragement we all had from Chris Booth. He was an enthusiastic and generous leader of the group, promoting individuality and encouraging potential. We are also indebted to the marvellous patients who were often as dedicated and as involved in clinical investigations as we were. A special name comes immediately to mind which other colleagues will readily recognise - Joe Hall - who did his own intubations and collected his own samples with the greatest precision. He kept a detailed diary of all events. Joe became a friend who still visits us socially. There were many others who joined in these studies and whom I frequently visited in their homes. It is evident that those were golden years at Hammersmith Hospital but for me all was to change when I married Chris Booth and we had our lovely daughter Nadya. I did not take easily to the role of Caesar's wife and it became obvious that I had not only to change hospitals, but also to change subjects. In 1973, I was fortunate enough to be appointed by Professor R A Shooter as lecturer in medical microbiology at $\mathrm{St}$ Bartholomew's Hospital, where I still work, having become Professor and Head of the Department in 1985.

Currently my main areas of research are the development of new methods for fingerprinting bacteria and the investigation into the molecular basis of infec- 


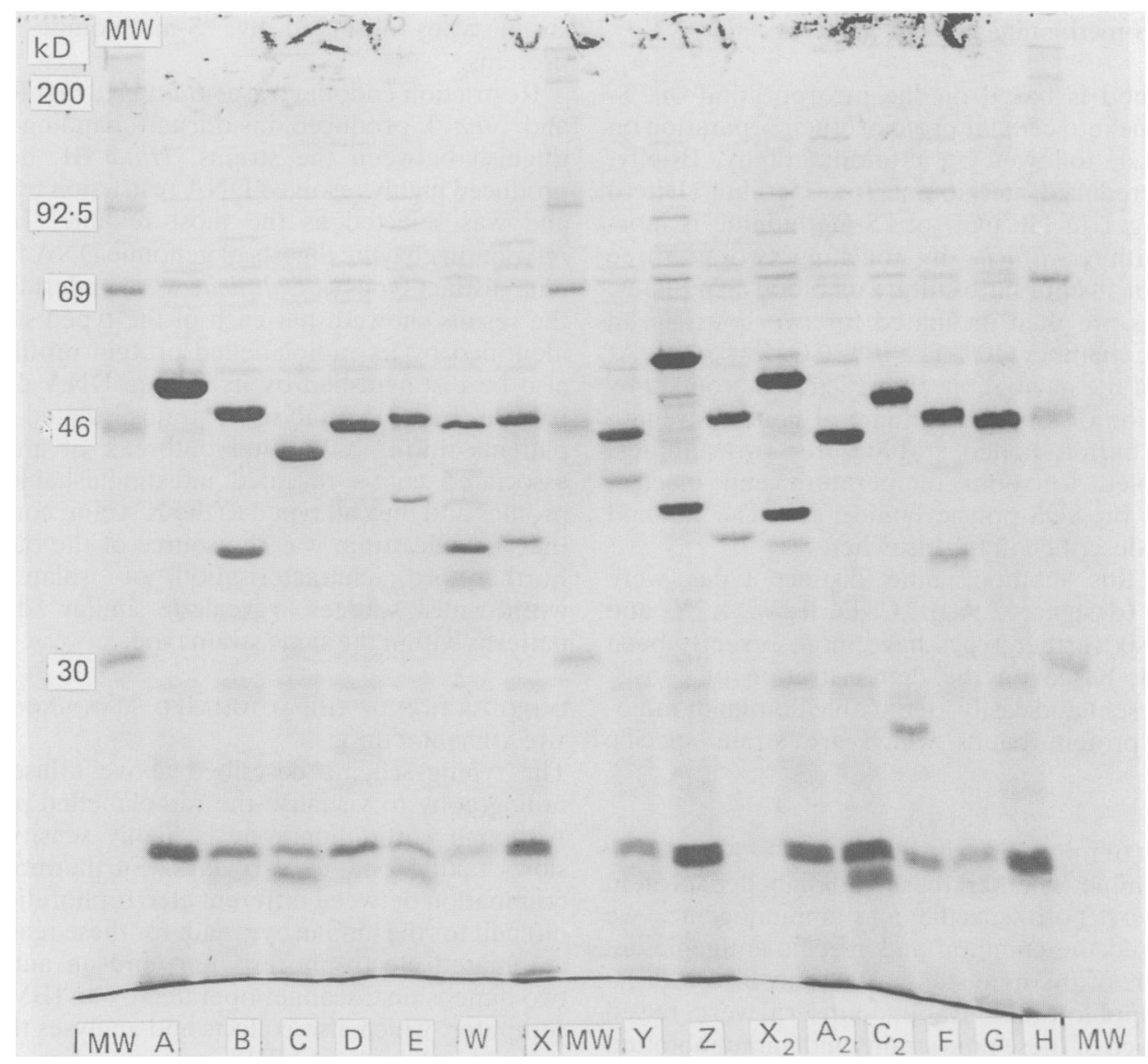

Fig. 1 Autoradiograph of "S-methionine labelled protein profiles from 15 types of Clostridium difficile. based on the dominant bands between 35 and $65 \mathrm{kDa}$. A-H, A2, C2, X2 and $W-X$; standard strains of Clostridium difficile. MW; Molecular weight standards.

tious diseases. Molecular cloning and genetic analysis of virulence factors and immunodominant antigens of important pathogens would elucidate the pathogenic mechanisms of these organisms and provide improved diagnostic tests. In this paper I would like to present our work on Clostridium difficile.

Clostridium difficile is now well established as the major enteric pathogen causing pseudomembranous colitis (PMC), and is implicated in cases of antibiotic associated colitis (AAC) and diarrhoea (AAD). ${ }^{3+}$ The patients most commonly affected are the immunocompromised, the elderly and those undergoing surgery, yet at the same time, there is asymptomatic carriage of $C$ difficile and its toxins in neonates and infants, ${ }^{5}$ an unexplained paradox.

Reports of clustering of cases of antibiotic associated colitis ${ }^{6}$ and early animal studies ${ }^{7 x}$ suggested that environmental contamination and cross infection might be important in the aetiology of outbreaks, but convincing evidence for nosocomial infections was lacking because of absence of reliable typing schemes. The introduction of suitable typing methods would be of value in elucidating the epidemiology of this organism and in differentiating between potentially pathogenic and non-pathogenic strains.

Wust et al' in 1982 applied a number of established methods to show that a single strain of $C$ difficile was the cause of an outbreak of antibiotic associated diarrhoea in a hospital, and Sell and coworkers in $1983^{1 \prime}$ were developing a bacteriophage and bacteriocin typing method for $C$ difficle.

In my laboratory we developed new methods based on "S-methionine labelled proteins, immunoblotting and DNA fingerprinting for differentiating between $C$ difficile strains and applied them in epidemiological studies of $C$ difficile-associated disease. 


\section{Use of 35S-methionine labelled proteins}

The method is based on the incorporation of ${ }^{35} \mathrm{~S}$ methionine into cellular proteins, their separation on SDS-PAGE followed by autoradiography. Briefly, $50 \mathrm{ul}$ prereduced methionine free medium (Difco) containing $1 \mu \mathrm{l}(10 \mu \mathrm{Ci})$ of ${ }^{35} \mathrm{~S}$-methionine is inoculated with $C$ difficile by touching two to three colonies of 48 hour pure culture on blood agar plates. The tubes are then incubated for two hours in an anaerobic chamber $\left(10 \% \mathrm{H}_{2}, 10 \% \mathrm{CO}_{2}, 80 \% \mathrm{~N}_{2}\right)$. At the end of the incubation, the reaction is stopped by the addition of an equal volume of double strength cracking buffer, boiled at $100^{\circ} \mathrm{C}$ for two minutes, then cooled to room temperature and electrophoresed on SDS-polyacylamide gel. The method has been described in full elsewhere. ${ }^{112}$

Using this method, nine distinct types were observed (designated A, B, C, D, E, W, X, Y, and $Z$ ), and six further types have more recently been identified, based on the demonstration of consistently present and easily identifiable dominant radiolabelled protein bands which are strain specific (Fig. 1).

IMMUNOBLOTTING (WESTERN BLOTTING)

To determine whether these radiolabelled protein bands were both specific and immunogenic, we investigated the common and specific antigenic determinants of the nine standard strains of $C$ difficile by immunoblotting. ${ }^{13}$ Rabbit antisera were raised against each of these nine strains and immunoblotted against homologous and heterologous antigen preparations of the nine strains and against Clostridium sordellii and Clostridium septicum..$^{13}$ The results showed the presence of shared common proteins (C1, C2 and C3) amongst the nine standard types with heterologous and homologous antisera, and in addition a type specific response with the homologous antiserum. Furthermore, when 35Smethionine-labelled $C$ difficile proteins were immunoblotted with homologous and heterologous antisera. both the immunoblots and the autoradiographs showed the same strain specific response. This work provided evidence that the dominant "Smethionine-labelled proteins produced on SDSPAGE are also strain specific and immunogenic. Furthermore, it demonstrated that a single antiserum is inadequate in providing a typing scheme.

DNA FINGERPRINTING

The application of bacterial restriction endonuclease analysis (BRENDA) of $C$ difficile DNA was also applied to provide an additional epidemiological tool and to confirm the distinctions between the various strain types observed by ${ }^{35} \mathrm{~S}$-methionine labelled proteins.

Restriction endonucleases Bam H1, Eco R1, Sal I and Sma I produced insufficient banding to distinguish between the strains. Hind III, however. produced highly resolved DNA restriction fragments and was selected as the most reliable. Hind III restriction enzyme digests of genomic DNA from the nine distinct types of $C$ difficile were undertaken and the results showed that each of the typed strains as identified by its radiolabelled protein profile could also be distinguished by its unique DNA digestion pattern (Fig. 2). Analysis of strains isolated from 10 patients during a hospital outbreak of antibioticassociated colitis revealed indistinguishable DNA profiles and they all typed as the $\mathrm{X}$ strain, confirming that a single strain was the source of the outbreak. Furthermore, characterisation of isolates from world-wide sources revealed similar digestion patterns within the same strain type. ${ }^{1+}$

INTRODUCTION OF THE AUTOMATED SCANNING SYSTEM: THE AMBIS MACHINE

The typing scheme described above utilises autoradiography to visualise the radiolabelled proteins. Although autoradiography is highly sensitve, it is slow, taking one to two days. Furthermore, discrimination between different electrophoretic runs is difficult for the human eye, and, for these reasons, an automated electrophoresis unit and an automated two dimensional scanner operated by an IBM pc/AT computer, which also collects and analyses the data, were developed (AMBIS system). For a more detailed description see Tabaqchali et al. ${ }^{15}$

The dried gels are scanned directly and the data are retrieved on the VDU as a picture resembling the autoradiograph. Each lane is then 'boxed' in and analysed. A histogram is produced for each lane, representing the density and width of each of the protein bands for the particular strain. The molecular weight standard channel is also extracted and a calibration curve drawn.

By applying various pattern recognition software and normalisation procedures, it has been possible to apply numerical analysis and produce a dendrogram for eight of the 14 types. Further work is in progress to improve the software and produce a system which would identify the strain and the type within five to six hours.

\section{Applications in epidemiological studies}

Surveys of routine faecal specimens arriving in the laboratory were undertaken to establish the isolation rate of $C$ difficile and its cytotoxin and to compare its incidence to that of other enteric pathogens. One 


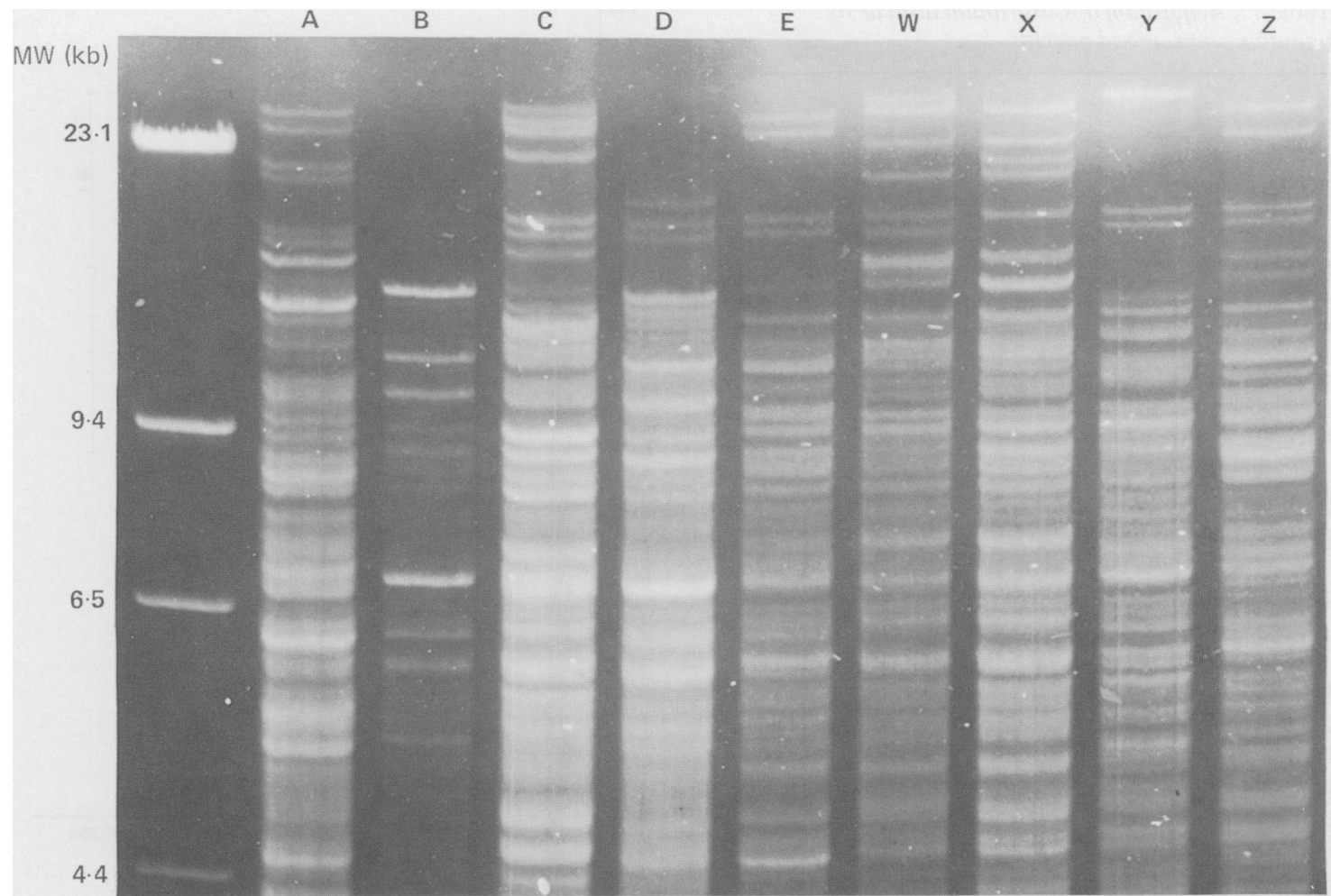

Fig. 2 Hind III restriction endonuclease DNA digests from genonmic DNA of the nine typed C difficile strains ( $A-D, W-Z)$ showing distinctive profiles. DNA size markers (in kilobases) are shown on left.

thousand two hundred and thirty nine consecutive specimens from 856 patients were examined. $C$ difficile was isolated from 69 patients giving an overall isolation rate of $8 \%$ with $32 \%$ in those under two years of age and $4 \%$ in those over two years of age. Cytotoxin producing strains were carried by $52 \%$ of positive patients and the percentage was higher in those over two years of age $64 \%$ compared to $46 \%$ in those under two years of age. Cytotoxin was detected in the stool of 10 patients; six infants and four adults.

The isolation rate of other enteric pathogens in the routine faecal specimens was less than that for $\mathrm{C}$ difficile; Salmonella sp were isolated from only 41 patients $(4.7 \%)$ and another 12 patients had Campylobacter or Shigella. The association of $C$ difficile with other pathogens was $20 \% .^{10}$

The typing scheme based on "S-methionine labelled proteins was applied to type strains isolated from patients and their environment from four hospitals." Ninety eight per cent of the 250 strains tested belonged to the nine types A-E and W-Z. Groups $X$ and $E$ were isolated from patients with antibiotic associated colitis and diarrhoea, whereas groups A-D were commonly isolated from vaginal specimens and from mothers and their asymptomatic neonates. ${ }^{117}$

\section{PROSPECTIVE EPIDEMIOLOGICAL. STUDY}

The typing scheme was also applied in a prospective six month study of immunocompromised patients during an outbreak of antibiotic associated colitis and diarrhoea and in general medical patients on two separate wards." The results showed that nosocomial acquisition of $C$ difficile and cross-infection occurred among immunocompromised patients. Cross infection presented a serious clinical problem and was controlled only after strict isolation procedures were implemented.

Two hundred and forty eight patients (1.35 oncology, 113 associated medical sharing the same ward were screened during the first 48 hours after admission for a period of six months. Nine hundred and eighty nine faecal samples were tested. Sixty two of the 248 patients were positive for $C$ difficile, 49 of 135 oncology and 13 of 113 associated medical patients. Of the 438 patients from a further two general medical wards. $17(3.9 \%)$ had positive 
Table I Acquisition of Clostridium difficile by immunocompromised patients

\begin{tabular}{|c|c|c|c|}
\hline \multirow{2}{*}{$\begin{array}{l}\text { Typing } \\
\text { of } \\
\text { struins }\end{array}$} & \multicolumn{3}{|c|}{ C difficile } \\
\hline & $\begin{array}{l}\text { Patients negative } \\
\text { on admission }\end{array}$ & $\begin{array}{l}\text { Patients positive } \\
\text { on admission }\end{array}$ & $\begin{array}{l}\text { Patients on ward } \\
\text { before start } \\
\text { of screen }\end{array}$ \\
\hline Type X & 22 & 2 & 11 \\
\hline Non-X & 7 & 7 & None \\
\hline
\end{tabular}

NB: $\chi=8 \cdot 49 ; p<0 \cdot(0005$

cultures for $C$ difficile, eight of those in association with antibiotic usage.

Typing the $C$ difficile strains isolated from these patients revealed that 35 of $49(71 \%)$ of oncology patients carried the same epidemic strain, type $X$, while the rest carried other types (A, D, E, W, Y). In contrast only three medical patients had type $\mathrm{X}$.

\section{ACQUISITION OF C DIFFICLE}

Of 29 oncology patients who were negative on admission, 22 acquired type $X(p<0 \cdot 005$; Table 1$)$ indicating nosocomial acquisition. Type $\mathrm{X}$ was also isolated from the environment particularly in the toilet and bath areas. ${ }^{18}$

\section{CORRELATION BETWEEN TYPE AND SYMPTOMS}

The relationship between type of $C$ difficile and symptoms is shown in Table 2 . Twenty nine of 33 $(88 \%)$ of symptomatic patients were carrying type $\mathrm{X}$ whereas six of $16(38 \%)$ of asymptomatic patients carried this type. This relationship was highly significant suggesting that the epidemic strain in the presence of precipitating factors may be particularly virulent. Typing of clinical specimens may therefore indicate which patients require early treatment and special management and may provide a means of distinguishing between colonisation and infection. ${ }^{19}$

The presence of symptoms with specific types ${ }^{1114}$ may in part be related to the ability of the strains to produce toxins. There was a direct relationship between the production of toxins $\mathrm{A}$ and $\mathrm{B}$ in all the

Table 2 Relationship between symptoms and the type of Clostridium difficile

\begin{tabular}{llll}
\hline & $\begin{array}{l}\text { Patients } \\
(n)\end{array}$ & $\begin{array}{l}\text { Epidemic strain } \\
\text { X-type }\end{array}$ & $\begin{array}{l}\text { Non-epidemic } \\
\text { strain }\end{array}$ \\
\hline $\begin{array}{l}\text { Symptomatic } \\
\text { patients }\end{array}$ & 33 & 29 & 4 \\
$\begin{array}{l}\text { Asymptomatic } \\
\text { patients }\end{array}$ & 16 & 6 & 10 \\
\hline
\end{tabular}

NB: $\chi:=14 \cdot 72 ; \mathrm{p}<0 \cdot(0) 1$

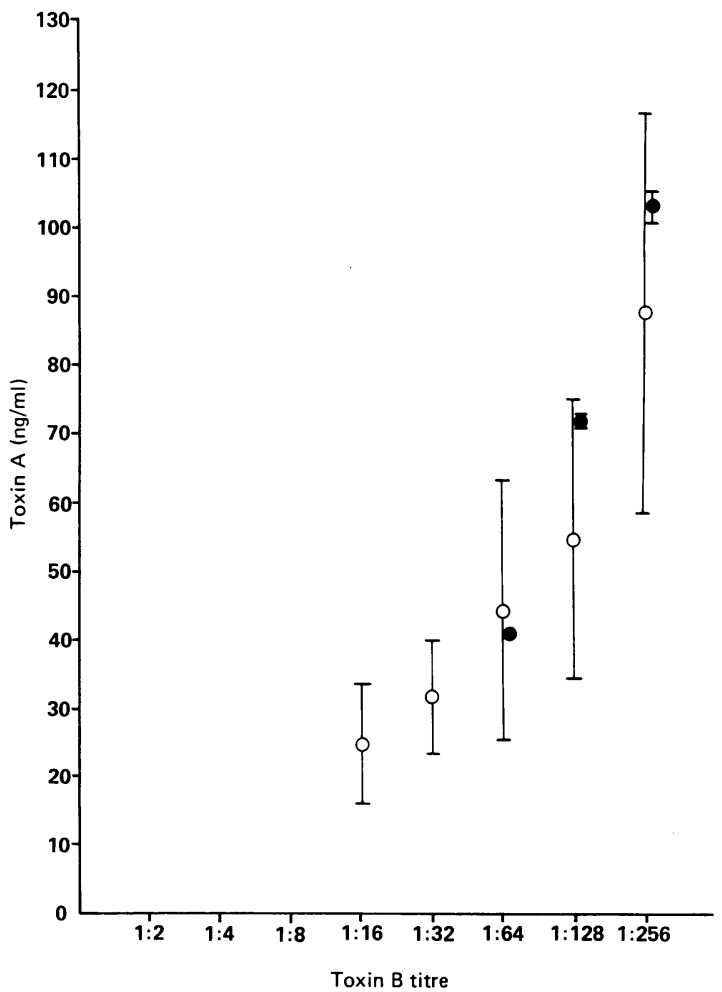

Fig. 3 Relationship between toxin $A$ and toxin $B$ production by clinical isolates of Clostridium difficile.

strains tested (Fig. 3). The relationship between toxin $\mathrm{A}$ and $\mathrm{B}$ production and the type of $C$ difficile was also investigated in 170 strains isolated from 62 patients." There was a correlation between toxin production and type of strains. One hundred and forty seven of 172 strains were either high toxin producers (toxin $\mathrm{A}>40 \mu \mathrm{g} / \mathrm{ml}$, toxin $\mathrm{B}>1: 128$ ) or low toxin producers and toxin was not detected from 28 strains. Types $\mathrm{A}$ and $\mathrm{Y}$ were consistently nontoxin producers whereas type $\mathrm{E}$ and $\mathrm{W}$ were highly toxigenic. Type $\mathrm{X}$ showed variable toxin production, but those $\mathrm{X}$-strains isolated from the symptomatic oncology patients were high toxin producers.

\section{Molecular cloning of virulence factors and key anti- gens of $\mathrm{C}$ difficile}

MOLECULAR CLONING OF C DIFFICILE TOXIN A

The pathogenicity of $C$ difficile has been linked to its toxin producing capabilities and in particular to its toxin A. Much controversy still exists regarding the biochemical and physical properties of toxin A such as amino acid content, isoelectric points and relative 


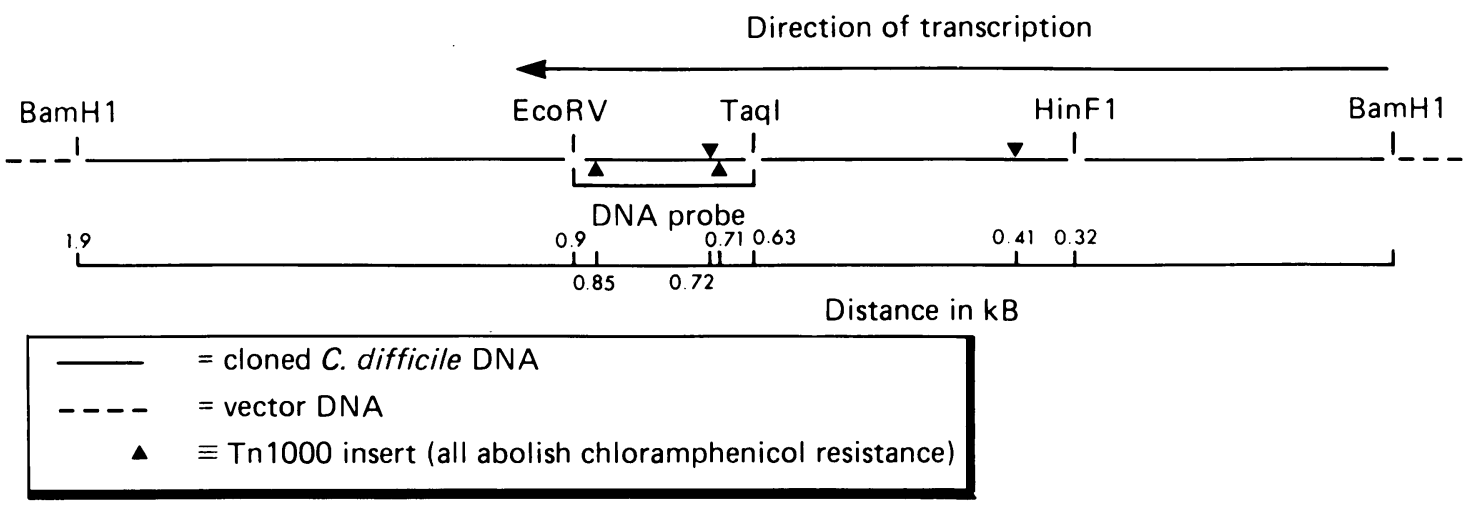

Fig. 4 Linearised restriction cleavage map of the $1.9 \mathrm{~Kb}$ insert from plasmid pPPM9. The Bam $\mathrm{Hl}$ site nearest the lac $Z$ gene in the vector DNA is taken as the origin for kilobase distance measurements.

molecular mass ranging from $57-600 \mathrm{kDa}$. A more definitive approach to its characterisation would be to use recombinant DNA techniques to clone the toxin A gene in E coli. The cloning and characterisation of the gene product would provide more definitive information on the polypeptide structure and mode of action. The clone would also be useful in developing a gene probe for epidemiological studies to determine the prevalence of the toxin and its relatedness to other toxins. A toxin A gene probe would be useful for the identification of toxigenic $C$ difficile strains directly in clinical specimens particularly with the use of the polymerase chain reaction (PCR) which enhances the sensitivity of the probe. $C$ difficile toxin $\mathrm{A}$ was purified to homogeneity and was used to raise antiserum in New Zealand white rabbits. A gene bank of $C$ difficile DNA in $E$ coli was constructed by cloning $S a u$ 3A-cleaved $C$ difficile DNA fragments $(9-20 \mathrm{~Kb})$ into the bacteriophage vector \EMBL3 which had been digested with Bam H1. Of 4500 plaques screened with absorbed antitoxin A serum, nine clones reacted positively. One of these clones, designated \tA5, was digested with Bam H1 or Sal 1 revealing an insert of $14.3 \mathrm{~Kb}$. Immunoblot analysis using the monospecific antitoxin A serum with the recombinant $\backslash \mathrm{tA}$ 5 showed a single protein band at $232 \mathrm{kDa}$ corresponding with purified toxin $\mathrm{A}$. This expressed $232 \mathrm{kDa}$ protein showed biological activity by exhibiting a cytotonic effect on hamster ovary cells, and having the ability to haemagglutinate rabbit erythrocytes, both properties characteristic of toxin A..$^{21}$ A gene probe is currently being developed to identify toxigenic strains and to apply in epidemiological studies.

\section{Molecular cloning of antibiotic resistance genes}

The manifestation of $C$ difficile associated disease invariably follows the administration of antibiotics, and multiresistant strains of $C$ difficile are often responsible for outbreaks of the disease."2 The cloning and genetic analysis of antibiotic resistance genes will help in evaluating the genetic basis of virulence and to use as selective markers for the construction of clostridial cloning vectors. Furthermore, antibiotic resistance genes have long been used as gene probes to study the dissemination and transfer of antibiotic resistance amongst several bacterial species but until recently this work has not been applied to $C$ difficile. The highly resistant strain of $C$ difficile, type W, ${ }^{1123}$ was also highly toxigenic and was isolated from a patient with pseudomembranous colitis. In order to examine the role of antibiotics and antibiotic resistance in $C$ difficile, we set out to clone:

(1) The chloramphenicol acetyltransferase (CAT) gene;

(2) The tetracycline (TET M) gene;

(3) The clindamycin-erythomycin resistance gene

GENETIC ANALYSIS OF CHLORAMPHENICOL RESISTANCE A gene bank from strain $\mathrm{W}$ expressing high chloramphenicol resistance was constructed by cloning Sau 3A cleaved clostridial DNA fragments into the plasmid vector pUC13. Among 1020 clones tested, 11 were found to be resistant to chloramphenicol, and one of those with an insert size of $1.9 \mathrm{~kb}$ (pPPM9) was studied further. This clone was mapped using a variety of restriction enzymes and $0.27 \mathrm{~kb} E c o \mathrm{RV} / \mathrm{Taq} \mathrm{I}$ restriction fragment was shown to be within the CAT gene encoding chloramphenicol resistance $\left(\mathrm{Cm}^{r}\right)$ using transposon (Tn 1000) mutagenesis (Fig. 4). The $0.27 \mathrm{~kb}$ fragment and the $1.9 \mathrm{~kb}$ insert were radiolabelled and used as DNA probes in hybridisation studies. Southern blot analysis using the gene probes against chromosomal DNA of $\mathrm{Cm}^{\mathrm{r}}$ strains from worldwide sources 
revealed at least two copies of the same CAT gene present in each strain. No hybridisation was observed with $\mathrm{Cm}^{r}$ Staphylococcus aureus, $S$ epidermidis, Klebsiella edwardsii, C innocuum, $C$ tertium and $C$ fallax but considerable homology was seen with $\mathrm{Cm}^{\mathrm{r}}$ gene derived from $C$ perfringens ${ }^{23}$ Sequencing of the CAT gene has been undertaken and the sequence (submitted for publication) is being compared with other known sequences of CAT genes from other gram positive bacteria including $C$ perfringens.

Colony hybridisation ${ }^{2+}$ was used to screen a number of $C$ difficile strains derived from worldwide sources from $\mathrm{Cm}^{r}$. All the strains which reacted positively with the probe belonged to type W.

\section{GENETIC ANALYSIS OF TETRACYCLINE RESISTANCE}

The tetracycline resistance gene from $C$ difficile has been cloned onto the plasmid, pUC13, into E coli. As described for the CAT gene a fragment totally within the gene has been determined. This fragment has been used as a probe in Southern blots against chromosomal DNA isolated from tetracycline resistant $C$ difficile strains from various geographical locations. These blots revealed that all resistant strains examined had at least one copy of the gene integrated in the same relative position on the chromosome. Tetracycline resistance was found to be transferable by filter mating between $C$ difficile strains, from $C$ difficile to Bacillus subtilis and from $B$ subtilis to $C$ difficile. After mating, the tetracycline resistance element appeared to integrate into two specific placed in the $C$ difficile chromosome and at random into the $B$ subtilis chromosome. ${ }^{25}$

\section{GENETIC ANALYSIS OF CLINDAMYCIN ERYTHROMYCIN RESISTANCE}

The macrolide resistance gene from $C$ difficile has also been cloned onto a cosmid vector. ${ }^{26}$ Erythromycin resistance can be transferred between $C$ difficile strains from $C$ difficile to $B$ subtilis and from $B$ subtilis to $C$ difficile (unpublished data).

IDENTIFICATION AND MOLECULAR CLONING OF A 70 KDA SPECIES-SPECIFIC ANTIGEN COMMON TO C DIFFICILE

The culture and identification of $C$ difficile is cumbersome and time consuming. More rapid diagnostic procedures are urgently needed to detect $C$ difficile in clinical specimens. Attempts have been made to introduce commercial kits but these have been unsuccessful, we therefore embarked on cloning a common antigen of $C$ difficile identified ealier by immunoblotting using homologous and heterologous antisera. A gene library of $C$ difficile genomic DNA was constructed in $E$ coli by cloning Sau $3 \mathrm{~A}$-cleaved $C$ difficile DNA fragments into bacteriophage vector $\backslash$ EMBL3. Out of 3000 plaques screened using whole cell antisera, 27 clones were positively identified. One of these clones, designated $\backslash \mathrm{CD} 21$ expressed high levels of an antigen against all the 9 antisera. The clone $\backslash \mathrm{CD} 21$ identified a $70 \mathrm{kd}$ antigen previously named (CB1) as shown by immunoblotting. Monospecific antiserum against $\backslash \mathrm{CD} 21$ recognises the $70 \mathrm{kd}$ antigen in all 88 strains of $C$ difficile derived from worldwide sources and does not cross-react by immunoblot with 16 strains from 11 other clostridial species. ${ }^{27}$ This monospecific antisera is now being evaluated as a possible probe for the identification and detection of $C$ difficile in clinical specimens.

I would like to thank all my colleagues who have been involved in this work and whose names appear on the publications. This work is supported by the Wellcome Trust, the Medical Research Council and the Joint Research Board, St Bartholomew's Hospital.

\section{References}

1 Gorbach SL, Tabaqchali S. Bacteria, bile and the small bowel. Gut 1969; 10: 963-72.

2 Tabaqchali S. The pathophysiological role of small intestinal bacterial flora. Scand J Gastroenterol 1970; [suppl 6]: 139-163.

3 Barlett JG. Antibiotic associated pseudomembranous colitis. Rev Infect Dis 1979; 1: 530-9.

4 Larson HE, Price AB, Honour P, Borriello SP. Clos tridium difficile and the aetiology of pseudomembranous colitis. Lancet 1978; i: 1063-6.

5 Donta ST, Meyers MB. Clostridium difficile toxin in asymptomatic neonates. J Paediatr 1982; 100: 431-4.

6 Fekety R, Kim K-H, Brown D, Baths DH, Cudmore M, Silva J Jr. Epidemiology of antibiotic-associated colitis: isolation of Clostridium difficile from hospital environment. Am J Med 1981; 70: 966-88.

7 Toshniwal R, Silva J Jr, Fekety R, Kim K-H. Studies on the epidemiology of colitis due to Clostridium difficile in hamsters. J Infect Dis 1981; 143: 51-4.

8 Larson HE, Price AB, Borriello SP. Epidemiology of experimental enterocolitis due to Clostridium difficile. $J$ Infect Dis 1980; 42: 408-13.

9 Wust J, Sullivan NM, Hardegger U, Wilkins TD. Investigation of an outbreak of antibiotic-associated colitis by various typing methods. J Clin Microbiol 1982; 16: 1096-101.

10 Sell TL, Schaberg DR, Dekerty FR. Bacteriophage and bacteriocin typing scheme for Clostridium difficile. $J$ Clin Microbiol 1983; 7: 1148-52.

11 Tabaqchali S, Holland D, O'Farrell S, Silman R. Typing scheme for Clostridium difficile: its application in clinical and epidemiological studies. Lancet 1984; i: 935-8.

12 Tabaqchali S, Holland D, O'Farrell S, Silman R. Method for the typing of Clostridium difficile based on polyacrylamide gel electrophoresis of 35S-methionine labelled proteins. J Clin Microbiol 1986; 23: 197-8.

13 Heard SR, Rasburn B, Matthews RC, Tabaqchali S. Immunoblotting to demonstrate antigenic and immuno- 
genic differences among nine standard strains of Clostridium difficile. J Clin Microbiol 1986; 24 : 384-7.

14 Wren BW, Tabaqchali S. Restriction endonuclease DNA analysis of Clostridium difficile. J Clin Microbiol 1987; 25: 2402-4.

15 Tabaqchali S, Silman R, Holland D. Automation in clinical microbiology: a new approach to identifying microorganisms by automated pattern matching of proteins labelled with ${ }^{35} \mathrm{~S}$-methionine. J Clin Pathol 1987; 40: 1070-87.

16 Nash JQ. Chattopadhyay B. Honeycombe J, Tabaqchali $\mathrm{S}$. Clostridium difficile and cytotoxin in routine faccal specimens. J Clin Pathol 1982; 35: 561-5.

17 Tabaqchali S, O’Farrell S, Nash JQ, Wilks M. Vaginal carriage and neonatal acquisition of Clostridium difficile. J Med Microbiol 1984; 18: 47-53.

18 Heard SR, O'Farrell S, Holland D, Crook S, Tabaqchali $\mathrm{S}$. The epidemiology of Clostridium difficile with use of a typing scheme: nosocomial acquisition and cross-infection among immunocompromised patients. $J$ Infect Dis 1986; 153: 159-62.

19 Heard SR, Wren B, Barnett MJ, Thomas JM, Tabaqchali S. Clostridium difficile infection in patients with haematological malignant disease: risk factors, faccal toxins and pathogenic strains. Epidemiol Infect 1988; 100: 63-72.

20 Wren BW, Heard SR, Tabaqchali S. Association between production of toxins $A$ and $B$ and types of Clostridium difficile. J Clin Pathol 1987; 40: 1397-401.
21 Wren BW, Clayton CL. Mullany PP. Tabaychali S. Molecular cloning and expression of Clostridium difficile toxin A in Escherichia coli K12. FEBS Letts 1987; 225: $82-6$.

22 Dzink J, Barlett JG. In vitro susceptibility of Clostridium difficile isolates from patients with antibioticassociated diarrhoca or colitis. Antimicrob $A g$ Chemother 1980; 17: 695-8.

23 Wren BW, Mullany P. Clayton C, Tabaqchali S. Molecular cloning and genetic analysis of a chloramphenicol acetyl transferase determinant from Clostridium difficile. Antimicrob Ag Chemother 1988; 32: 1213-7.

24 Grunstein M, Hogness DS. Colony hybridsation: a method for the isolation of cloned DNAs that confirm a specific gene. Proc Natl Acad Sci USA 1975; 72: 3961-5.

25 Mullany P, Wren BW, Wilks M. Clayton C. Tabaqchali $\mathrm{S}$. Genetic analysis of a conjugative transposon-like element from Clostridium difficile. J Med Microbiol 1989; 28: iii.

26 Wren BW, Mullany P. Clayton C, Tabaqchali S. Molecular cloning and expression of Clostridium difficile toxin $\mathrm{A}$ and macrolide resistance determinants in Escherichia coli. [Abstract] Gut 1988; 29: A723.

27 Wren B.W. Mullany PP, Clayton CL. Tabaychali S. Identification and molecular cloning of a $70 \mathrm{kDa}$ speciesspecific antigen common to Clostridium difficile. FEMS Microbiol Immunol 1988; 47: 163-8. 